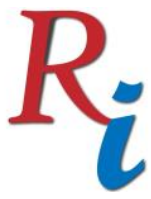

Asia Proceedings of Social Sciences

(APSS)

www.readersinsight.net/APSS

\title{
A SySTEMATIC LITERATURE REVIEW ON CASH CROP PRODUCTION
}

\author{
Ja'afaru Yusuf Dogara*
}

Department of History

University of Malaya

Malaysia

jafaruyusufdogara@gmail.com

\section{Hamidin Abd Hamid}

Department of History

University of Malaya

Malaysia

hamidin@um.edu.my

*Corrosponding author's Email: jafaruyusufdogara@gmail.com

Peer-review under responsibility of 4th Asia International Multidisciplinary Conference 2020 Scientific Committee

http://connectingasia.org/scientific-committee/

(C) 2020 Published by Readers Insight Publisher

lat 306 Savoy Residencia, Block 3 F11/1,44000 Islamabad. Pakistan,

editor@readersinsight.net

This is an open access article under the CC BY-NC-ND license (http://creativecommons.org/licenses/by-nc-nd/4.0/). 


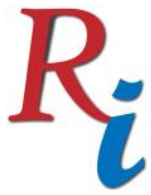

\section{Asia Proceedings of Social Sciences (APSS) \\ www.readersinsight.net/APSS}

\section{A b s t r a c t}

Works of literature have clearly attested to the fact that cash crop production as a global phenomenon has a track of history. Past and contemporary scholars on economics, agriculture, and history show little commitment to the subject matter of cash crops production globally. Related studies are reviewed in order to develop sensible solutions and add value to the limited sources on the area (finding). Thus, this research aims at a systematic literature review of relevant literatures on cash crop production. Literatures that relates to the subject matter are assembled, examined, and incorporated according to the need of this systematic literature review. We focus on the studies that encompasses cash crop sustainability, cash crop smallholders/small-scale/households, cash crop farming/farmers, cash crop and food production, groundnut production, sustainable groundnut production, groundnut seed production, groundnut small-holders farmers, and contribution, impact, and the role of groundnut production on the economy.

\section{Rese a r ch H i g h I igh t s}

Cash Crop farming over time remains a means of growing income, security for smallholder farmers, improve food security, and sustainable agricultural development Anderman, Remans, Wood, DeRosa, \& DeFries, (2014). Willcox (1937), Okwuosa (1975) examined cash crop production and family structure in West Africa. Amatya (1975) focuses his attention on the relevance of cash crop farming. West (1976) dwells on expansion of agriculture sector, food supply, and population growth in Latin America, Tosh (1980) dwells on cash crop transformation in Africa. FAO of the United Nations \& DANIDA ( 1981) small-scale cash crop farming has become the aspiration of South Asia. Hogendorn and Gemery (1982) considered cash cropping as a source of currency acquisition in West Africa from 1923-1950. Pancake (1999) offer the cash crop history from 1897.

Fafchamps (1992), Woodward (1995) indicates the rationality of Cash Crop Production policies

Goetz (1992) reveals that technology and perceived associated prices are key to production of food crop and cash high (crop output).

Brown and Kennedy (2005) found that cash cropping and agricultural commercialisation is a tool for relieving poverty to small landholders.

Hillocks (2001) looks at the challenges facing the small-scale farmers in Africa.

Govereh and Jayne (2003) believes that cash crop commercialisation schemes encouraged investment in a specific field that delivers profits to concerned farmers.

Barbier (1989); Fox, Klausner, Tylutki, \& Hanchar, (1994) and Partap, (1998)studies on cash crop sustainability 


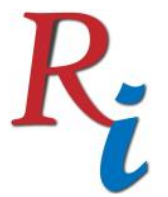

Asia Proceedings of Social Sciences

(APSS)

www.readersinsight.net/APSS

\section{Research Objectives}

The central objective of this article is to consolidate a systematic literature review that relates to cash crop production with a clear intention to classify the effort of the past and present scholars with a view to detect the existing gap that might give way for the conduct of research that relates to the History of cash crop production and underdevelopment

\section{Methodology}

To prepare this systematic literature we navigated using guide of the Centre for Reviews and Disseminations (DSR), nevertheless, with certain adaptation that suit the envisioned nature of this systematic review. We employed three sets of rich databases that involve (web of Science Core Collection TR, Library of Congress, and LISTA EBSCO) to search for the relevant documents. These databases are used through online endnote search mode to gather the relevant materials for the study). In addition to that, the authors did not confine the search to any limited period. The purpose of this flexibility is to allow the inclusion of the literature with the historical aspects to emerge from the search result so that the older publications could be reflected to allow history to take its cause. The search length was between the end of July and early month of August 2019.

The approaches include strict restriction to the English relevant literature, although there are likely many studies that relates to the subject of our discussion in languages other than English language (such as Malay, French, German, Arabic, etc). However, our main concern with regard to this study at hand is restricted to English language relevant documents. Thus, any study outside the scope of our criteria is castoff.

We strictly adhered to certain criterias that are in line with the needs of the systematic literature review.

\section{Results}

The study exposes the determinations of contemporary researchers with regard to literature that has direct connection cash crop production. The outcome of the printed literature was broken into 6 themes that show the existing efforts of the research scholars as depicted in the taxonomy of the key literature. The outcome of the study reveals that cash crop production has direct relationship and significant benefits with the cash crop smallholders/household; cash crop production policies; cash crop sustainability; cash crop farming/farmers, cash crop and poverty alleviation, and cash crop commercialization as indicated by numerous studies. We looked at values of the available literature of cash crop production and its pivotal role in motivating human well-being, poverty alleviation, smallholders/household, environmental sustainability, and the entire human society. In fact, we emphasised these values as highlighted by the academic researches. We, therefore, considered it important to discuss the results according to 


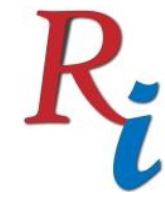

\section{Asia Proceedings of Social Sciences (APSS) \\ www.readersinsight.net/APSS}

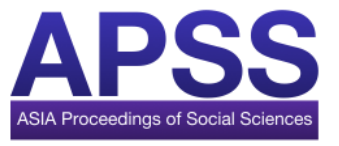

the themes that emerged in this study. The outcome of these themes is therefore provided coherently and in accordance with the need of this study.

\section{Findings}

The outcome of the systematic review reveals that both past and contemporary scholars indicate concern and commitment on the available themes of the results that emerged regarding the cash crop production. The result of the study further divulge that both past and contemporary scholars took more interest in the area of cash crops and smallholders/households than other potential themes.

The study has an implication, to historians, politicians, economists, cooperatives, academicians, policymakers, and large, medium, and smallholders cash crop farmers that might possibly reflect it as an excellent and relevant tool in the pursuance of their goals.

This review is unique and original in its form, it is also valuable to those that might appreciate its contents or potentially find it applicable to their comfortable circumstance

\section{References}

Amatya, S. L. (1975). Cash crop farming in Nepal. Kirtipur: Geography Instruction Committee, Institute of Humanities and Social Sciences, Tribhuvan University.

Anderman, T. L., Remans, R., Wood, S. A., DeRosa, K., \& DeFries, R. S. (2014). Synergies and trade-offs between cash crop production and food security: A case study in rural Ghana. Food Security, 6(4), 541-554. doi:10.1007/s12571-014-0360-6

Barbier, E. B. (1989). Cash Crops, Food Crops, and Sustainability - the Case of Indonesia. World Development, 17(6), 879-895. doi:Doi 10.1016/0305-750x(89)90009-0

Brown, S., \& Kennedy, G. (2005). A case study of cash cropping in Nepal: Poverty alleviation or inequity? Agriculture and Human Values, 22(1), 105-116. doi:10.1007/s10460004-7234-z.

FAO of the United Nations, \& DANIDA. (1981). Small-scale cash crop farming in South Asia: seminar proceedings: FAO/DANIDA regional seminar held at the Agrarian Research and Training Institute, Colombo, Sri Lanka, 15-27 October 1979. Rome: Food and Agriculture Organization of the United Nations.

Fafchamps, M. (1992). Cash Crop Production, Food Price Volatility, and Rural Market Integration in the Third-World. American Journal of Agricultural Economics, 74(1), 90-99. doi: Doi 10.2307/1242993

Fox, D. G., Klausner, S. D., Tylutki, T. P., \& Hanchar, J. J. (1994). Cows, Crops, and Cash Making Dairy Farms Sustainable. 1994 Cornell Nutrition Conference for Feed 


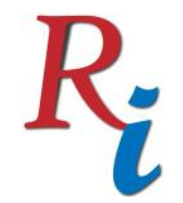

\section{Asia Proceedings of Social Sciences}

(APSS)

www.readersinsight.net/APSS

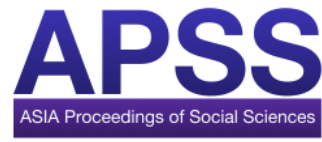

Manufacturers, Proceedings, 47-55. Retrieved from <Go to ISI>://WOS:A1994BC07D00005

Govereh, J., \& Jayne, T. S. (2003). Cash cropping and food crop productivity: synergies or trade-offs? Agricultural Economics, 28(1), 39-50. doi:PII S0169-5150(02)00066XDOI 10.1111/j.1574-0862.2003.tb00133.x

Goetz, S. J. (1992). Economies of Scope and the Cash Crop - Food Crop Debate in Senegal. World Development, 20(5), 727-734. doi:Doi 10.1016/0305-750x(92)90148-O

Hillocks, R. (2001). Coffee: is it still a viable cash crop for smallholders in Africa? Outlook on Agriculture, 30(3), 205-211. doi: Doi 10.5367/000000001101293661

Hogendorn, J. S., \& Gemery, H. A. (1982). Cash Cropping, Currency Acquisition and Seigniorage in West-Africa from 1923-1950. African Economic History(11), 15-27. doi: Doi 10.2307/3601215

Okwuosa, A. C. (1975). Consequences of the cash-crop economy for the family structure of selected societies of West Africa (Nigeria and Ghana). (Thesis), Freiburg i. B., Freiburg i. Br.

Pancake, A. (1999). 'Cash Crop, 1897'. Massachusetts Review, 40(1), 11-25. Retrieved from <Go to ISI>://WOS:000080209000003

Partap, T. (1998). Mountain agriculture, cash cropping and sustainability prospects. Crop Productivity and Sustainability: Shaping the Future, 561-572. Retrieved from <Go to ISI >://WOS:000087148800044

Tosh, J. (1980). Cash-Crop Revolution in Tropical Africa - Agricultural Reappraisal. African Affairs, 79(314), 79-94. doi:DOI 10.1093/oxfordjournals.afraf.a097201

West, Q. M. (1976). Food and cash crop competition. Basic Life Sci, 7, 163-169. Retrieved from http://www.ncbi.nlm.nih.gov/pubmed/952640

Willcox, H. L. (1937). The cash crop. New York: Friendship Press. 